\title{
Root Beer Flavor
}

National Cancer Institute

\section{Source}

National Cancer Institute. Root Beer Flavor. NCI Thesaurus. Code C73414.

A characteristic of a medicinal product, specifying that its most predominant agreeable savor detected by the unified sensation of taste and olfactory receptors resembles root beer. 